\title{
The double helix 50 years on: models, metaphors, and reductionism
}

\section{R E Ashcroft}

\section{Bioethics should update its conception of the gene}

$\mathrm{T}$ he 25th of April marks the 50th anniversary of the publication in Nature of the letter by James Watson and Francis Crick announcing their solution to the structure of deoxyribose nucleic acid (DNA). ${ }^{1}$ By that time, much was known about the role of chromosomes in inheritance, the contribution of DNA to chromosome structure, and the chemistry of DNA. ${ }^{2}$ The gene concept itself was also well established by then; the principal scientific problem became to specify what genes were in molecular terms and how they functioned in the cell during ordinary function and cell division.

The importance of the solution of the structure of DNA was twofold. First, it gave insight into finding a mechanism for DNA replication, as the authors recognised in this famous sentence:

It has not escaped our notice that the specific pairing we have postulated immediately suggests a copying mechanism for the genetic material. ${ }^{3}$

Second, it showed how Erwin Schrödinger's suggestion that genetic information could be represented as a one dimensional aperiodic crystal could actually work in material terms. ${ }^{45}$

It has been argued that the cultural power of the Watson/Crick model of DNA turns on two things. Firstly, there is the beautiful and memorable image of the double helix itself, which has become as instantly recognisable a symbol as the Coca Cola bottle or the sign of the Cross. ${ }^{67}$ This symbol has become a metonym for life itself. Secondly, there is the image of the processes of life being somehow governed by a very long string of instructions, coded with an elementary letter code, ACGT. ${ }^{89}$ According to this image, life is seen as reducible to a superficially very simple material basis, analogous to message transmission in information theory or a sort of computer programme. Even attempts to loosen this image of exact determination of life processes by the string of instructionthrough likening genes to blueprints or to cookbook recipes-do not stray too far from this image. ${ }^{10}$ Biologists themselves recognise this, and some attempts have been made recently to discuss this in philosophical and public fora-but these lack the power of the simple image. ${ }^{11}{ }^{12}$ The Watson/Crick image of DNA is a model for understanding certain aspects of biological inheritance, which has proved to be highly effective over the past 50 years in both science and society. ${ }^{13} 14$

Since 1953, this model has been elaborated and complicated. Attention to the functioning of the cell as a biochemical system and to developmental processes in embryogenesis, cell differentiation, and cancer biology has led biologists to move away from consideration of DNA as a "master molecule" which "acts" to direct the functioning of the cell. ${ }^{15}$ The information theoretic notion of the gene in the cell remains dominant in much discussion of "genethics", yet this is arguably no longer central in cell biologists' thinking about the gene. ${ }^{16}$

Simple ideas of genetic determination of traits still govern much of bioethicists' thinking about what genes do, and how. ${ }^{17}$ We greatly underestimate the ways in which different conceptions of the gene have different conceptual structures, explanatory force, and types of evidential support in evolutionary biology, molecular biology, embryology, and clinical medicine. ${ }^{18} 1920$ When challenged about reductionism or talk of "genes for" we become more subtle, but subtlety is hard to keep up! $!^{21} 22$ In this, the influence of the Human Genome Project on bioethics has been most unfortunate, in that it has concentrated our attention on one, rather narrow, if hugely time and resource consuming, approach to understanding the nature of the gene. ${ }^{23}$ The thought that by printing out the genetic code we will understand the whole programme, while not taken seriously even by the architects of the Human Genome Project, continues to dazzle many of us. ${ }^{24}$ More generally, the idea of chromosomal structure as a programme has a structure as a metaphor which disposes us to think in mechanical and deterministic terms about how cells, bodies, and lives develop.

It is high time to review the history of "genethics" since 1953, to revisit our own ideas of what 1953's papers mean for us today, and to challenge the unhelpful and simplistic notions of genetic causation which we have inherited. Only then can we effectively understand, challenge, or defend contemporary developments in sequencing, gene therapy, association studies in medicine, psychology, and criminology, and pharmacogenetics. Molecular biology has moved on, and so should we. Our use of scientific models in ethics should both keep up with the models in play in current science, and grasp their limits.

\section{ACKNOWLEDGEMENTS}

Thanks to Ainsley Newson, Tim Lewens, Mike Parker, and Julian Savulescu for helpful comments.

J Med Ethics 2003;29:63-64

\section{Author's affiliations}

R E Ashcroft, Imperial College London, UK

Correspondence to: Dr R E Ashcroft, Imperial College London, Department of Primary Health Care and General Practice, Reynolds Building, St Dunstan's, London W6 8RP, UK; r.ashcroft@imperial.ac.uk

\section{REFERENCES}

1 Watson JD, Crick FHC. A structure for deoxyribose nucleic acid. Nature 1953;171:737-8.

2 Olby R. The path to the double helix: the discovery of DNA [2nd ed]. New York: Dover, 1994

3 See reference 1: 737

4 Schrödinger $E$. What is life? With mind and matter and autobiographical sketches. Cambridge: Cambridge University Press, 1992.

5 Stent GS. The aperiodic crystal of heredity. Ann N Y Acad Sci 1995;758:25-31.

6 Nelkin $\mathbf{D}$, Lindee MS. The DNA mystique: the gene as a cultural icon. New York: WH Freeman, 1996.

7 Keller EF. The century of the gene. Cambridge, MA: Harvard UP, 2000

8 Keller EF. Refiguring life: metaphors of twentieth century biology. New York: Columbia University Press, 1996

9 Kay L. Who wrote the book of life? A history of the genetic code. Stanford: Stanford University Press, 2000.

10 Rose H. Love, power, knowledge: towards a feminist transformation of the sciences. Cambridge: Polity Press, 1994.

11 Maynard Smith J. The concept of information in biology. Philos Sci 2000;67:177-94.

12 Bateson P, Martin P. Design for a life: how behaviour develops. London: Vintage, 2000.

13 Morgan MS, Morrison M, eds. Models as mediators: perspectives on natural and social science. Cambridge: Cambridge University Press, 1999.

14 Van Fraassen BC. The scientific image. Oxford: Oxford University Press, 1980.

15 Nature special web resource to mark the 50th anniversary of DNA. See www.nature.com/ nature/dna50/index.html laccessed 7 February 2003) and follow the links to the index.

16 Nurse P. Reductionism and explanation in cell biology. In: Bock GR, Goode J. The limits of reductionism in cell biology (Novartis Foundation symposium 213) Chichester: John Wiley, 1998: 93-105

17 Beckwith J. The hegemony of the gene. In:Sarkar S, ed. The history and philosophy of molecular biology. Amsterdam: Kluwer Academic, 1996: 171-83.

18 Sarkar S. Genetics and reductionism. Cambridge: Cambridge University Press, 1998

19 Moss L. What genes can't do. Cambridge, MA: MIT Press, 2003 
20 Lewens T. Development aid: on ontogeny and ethics. Studies in History and Philosophy of Biological and Biomedical Sciences 2002;33:195-217

21 Wachbroit R. The question not asked: the challenge of pleiotropic genetic tests. Kennedy Inst Ethics J 1998;8: 131-45.
22 Kitcher $\mathbf{P}$. Battling the undead: how land how not) to resist genetic determinism. In: Singh RS, Krimbas CB, Paul DB, et al, eds. Thinking about evolution: historical, philosophical, and political perspectives. Cambridge: Cambridge University Press, 2000: ch.20.
23 Rosenberg A. The human genome project: research tactics and economic strategies. Soc Philos Policy 1996;13:1-17

24 Cook-Deegan RM. The gene wars: science, politics and the human genome. New York: WW Norton, 1994. 